\title{
Savaşın Değişen Doğası ve Clausewitz: "Savaş Üzerine” Eleştiriler
}

\section{The Changing Nature of War and Clausewitz: Criticism "on War"}

\author{
Mehmet Öztürk ${ }^{\mathrm{a}, *}$ \\ ${ }^{a}$ Dr. Öğr. Üyesi, Aksaray Üniversitesi, İktisadi ve İdari Bilimler Fakültesi, Uluslararası İlişkiler Bölümü, Aksaray/Türkiye. \\ ORCID: 0000-0003-3556-9216.
}

\begin{tabular}{l} 
MAKALE BİLGİSİ \\
Makale Geçmişi: \\
Başvuru tarihi: 01 Ocak 2020 \\
Düzeltme tarihi: 26 Mayıs 2020 \\
Kabul tarihi: 05 Haziran 2020 \\
\hline Anahtar Kelimeler: \\
Clausewitz \\
Savaş Üzerine \\
Yeni Savaşlar \\
Postmodern Savaş \\
Eleştiri
\end{tabular}

\section{A R T I C L E IN F O}

\section{Article history:}

Received 01 January 2020

Received in revised form 26 May 2020

Accepted 05 June 2020

Keywords:
Clausewitz
On War
New Wars
Postmodern War
Criticism

ÖZ

Sosyal bir olgu olan savaş, tarihin her döneminde kendine bir alan bulmayı başarmıştır. Buna kayıtsız kalamayan pek çok filozof, bu realite ile yakından ilgilenmiş ve kendi tezlerini ortaya koymuştur. Bunlardan birisi, Savaş Üzerine isimli eserinde ortaya koyduğu fikirlerle Prusyalı asker ve teorisyen Carl von Clausewitz (1780-1831) olmuştur. Onun eseri ve felsefesi, savaşla ilgilenen kesimlerin yakın ilgisini çekmiş ve kendinden sonra çok sayıda çalışmanın odağını oluşturmuştur. Bununla birlikte yapılan çalışmalarda "savaş üzerine" eleştiriler sınırlı kalmıştır. Bu çalışma; yeni ve postmodern savaş olgularından yola çıkıldığında savaşın değişen doğası karşısında Clausewitz'in görüşlerinin konumunu incelemeyi amaçlamıştır. Yapılan analizde özellikle mutlak savaş, üçleme, savaş-politika ilişkisi ve rasyonellik üzerinden Clausewitz'e eleştiriler yöneltebilmenin mümkün olduğu görülmüştür.

\section{Giriş}

Arapça "harp" sözcüğünden gelen "savaş" kelimesi, zaman içinde ontolojik ve epistemolojik olarak farklı bağlamlarda kullanılabilen bir kavram olagelmiştir. Bu durum, üzerinde uzlaşılan bir savaş tanımının yapılmasını tabiatıyla zorlaştırmıştır. Bununla birlikte geleneksel savaş tanımında birtakım özellikler ön plana çıkmaktadır: Kuvvet kullanmayı içermesi, düşmanca bir eylemi barındırması, hukuki bir durum oluşturması ve devletler ya da devlet gruplarının milli güç unsurlarını kullanarak bu savaşın bizzat yürütücüsü konumunda olmaları (Varlık, 2013: 115118). Tanımındaki zorluğa rağmen uzun ve entrikalarla dolu bir tarihe sahip savaş, düşman tarafların sorunlarını güç kullanarak çözmeye yönelmelerinden beri insanlığın kalıcı bir niteliği halini almıştır. Öyle ki bazı halkların tarihi, savaşlarının tarihleriyle özdeş görülmeye başlanmıştır (Kohn, 2006: vii).

\footnotetext{
* Sorumlu yazar/Corresponding author.

e-posta: mehmetozturk@aksaray.edu.tr
} 
Savaşı, "uyuşmazlıklarını zorlama yollarına başvurarak çözmeye çalışanların karşılıklı durumu" olarak tanımlayan Hugo Grotius'a (2011: 31-32) göre, söz konusu savaşa barışı sağlamak için girişilmektedir ancak savaşa neden olmayacak hiçbir uyuşmazlık da bulunmamaktadır. Dolayısıyla savaşın sosyolojik bir olgu olarak her zaman meydana gelebilecek doğal bir oluşum olduğu göze çarpmaktadır. Bu durumu İbni Haldun Mukaddime'sinde (2018: 556) şu şekilde açıklar:

"Malûm olsun ki, savaş ve vuruşmaların her çeşidi, Allah'ın varlıklarl yarattığ günden beri devam etmektedir. Savaşların kaynă̆ ise, insanların birbirinden öç almak istemeleridir. Savaşlarda herkes kendi asabiyetinden destek alır. Her iki grup kendi mensuplarını öç almaya teşvik eder ve her iki grup saf saf toplandlktan sonra, biri intikam, birisi kendini korumak için, savaşa girer. Bu, beşer için tabii bir hâl olup, hiçbir millet ve nesil bundan hâli değildir (uzak kalamaz)."

Sosyal bir olgu olan savaş, tarihi süreçte pek çok filozofun ilgisini çekmiştir. Örneğin kendini koruma güdüsü ve arzusunun insan davranışları üzerinde önemli bir etkiye sahip olduğunu düşünen St. Augustine (aktaran Waltz, 2009: 22) savaşın barış adına yapılması gerektiğini söyleyerek savaşın haklılığı üzerine Hıristiyanlıkta ilk düşünceyi ortaya çıkaran kişi olmuştur. Kiliseyi korumak için yapılan savaşları haklı savaş olarak tanımlayan Aquinolu Thomas'ın (2002: xxx), İncil'in yasaklamasına rağmen savaş kavramının bazı şartlara bağlanarak haklı olabileceğine yönelik savaşı haklılaştıran düşüncesi, kendisinden sonra Avrupa haçlı seferleri, kara veba ve yüzyıl savaşlarının yaşanmasına sebebiyet vermiştir (Yalçınkaya, 2008: 49-51). Prens çalışmasıyla da tanınan Machiavelli Savaş Sanatı isimli çalışmasında savaş sanatının detaylarına inerek şöyle der (2007: 49): "Devamlı eğitim ve disiplin bir orduyu formda ve ani bir çarpışma için hazır tutacaktır. Bu amaçla prens ve yanındakiler için barış zamanındaki en iyi eğitim avdır."

Hobbes'a (2010: 101) göre ise, insan doğasında onu çatışmaya yöneltecek unsurlar rekabet, güvensizlik, şan ve şereftir. Bunlar insanı kazanç, güvenlik ve şöhret için mücadele etmeye yöneltir. Devletin olmadığı bu doğa durumunda "herkes herkese karşı daima savaş halindedir". Ona göre, savaşın doğası, "çarpışma eyleminden ibaret olmayıp, tersine bir güvencenin bulunmadığı, çarpışmaya yönelik kesinleşmiş eğilimden oluşur”.

Thucydides'in ünlü Peloponez Savaşı'nda belirtilen klasik realizmin ilk ifadelerini bulan Melianlılar ile Atinalılar arasındaki diyalogda Atinalılar şöyle derler: "Güçlü neye gücü yetiyorsa onu yapar, zayıf da kabul etmek zorunda olduğu şeyi kabul eder”. Yine Melianlıların düşmanlık yerine arkadaşlık teklifine Atinalılar şöyle karşılık verirler: "Bize zarar veren sizin düşmanlığınız değil; aksine, sizin düşmanlığınız bizim gücümüzün kanıtı iken sizinle dost bir tavirda olmamı durumunda halkımızın bunu, bizim zayıflığımız olarak görmesidir" (2016: 84-85).

Yaklaşık 2500 yıl önce Çinli filozof Sun Tzu, Savaş Sanatı (Sunzi Bingfa) adlı eserinde, güvenliğe kavuşmanın ya da yok olmanın temel belirleyicisi olarak gördüğü savaş sanatının, bir devlet için hayati öneme sahip olduğunu vurgular. Ayrıca savaş koşullarında mutlaka dikkate alınması gereken kuralların ahlak/uyum, hava/tabiat, arazi/savaş alanı, liderlik, disiplin olduğunu belirtir (2010:5,47). Savaş ve strateji konusunda Sun Tzu'dan sonra savaşa dair en önemli çalışmalardan birisini ve bu çalışmanın da temel referans kaynağı olan Clausewitz'in "Savaş Üzerine" eseri oluşturur. Batının stratejik geleneklerini yansıtan Clausewitz ve onun eseri, literatürde önemli bir övgüye mazhar olsa da yine de birtakım tartışmaya ve eleştiriye maruz kalmıştır (Milevski, 2019: 139).

Clausewitz'in savaş kuramının günümüzde geçerliliğine yönelik tartışmalarda üç farklı yönelimden söz edilebilir. İlk olarak, Clausewitz'in savaş anlayışının geçerliliğini savunanlara göre; Clausewitz'in savaş teorisi teknik yönlerden olmasa bile mantığı veya felsefi özü devam etmektedir. İkinci olarak, Clausewitz'in savaş teorisinin ana unsurlarını koruyarak reform yapılmasını savunan görüşe göre; modern savaş koşullarını tümüyle değiştiren siyasi, sosyal, psikolojik ve bürokratik alanlarda zincirleme etki oluşturan teknolojik yenilikler ile savaşların ekonomik ve ahlaki boyutu gibi unsurlar kurama dâhil edilmelidir. Üçüncü olarak, Clausewitz'in savaş anlayışına tamamen karşı çıkanlara göre; Clausewitz'in savaş kuramı geçerliliğini yitirmiştir ve bu kuramı ıslah etme çabaları da yersizdir (Oyan Altuntaş, 2008: 209). Literatürde Clausewitz'in görüşlerini doğrudan ya da reforme edilmesi halinde geçerliliğini savunan Pappila (2008), Creswell (2011), Stone (2007), Strachan (2007), Schuurman (2014), Herberg-Rothe (2009), Čajić (2016) gibi pek çok çalışmanın bulunduğu görülmektedir.

Bu çalışmada yukarıdaki gibi bir tasnife gidilmekten ziyade bilhassa savaşın değişen doğası öne çıkarılarak Clausewitz'in savaş üzerine retoriklerini eleştiren görüşlere yer verilecektir. Bu eleştirileri anlamlı hale getirebilmek ve sağlam zeminde ortaya koyabilmek için öncelikle Clausewitz'in Savaş Üzerine isimli eserine değinilecektir. İkinci olarak, savaşın değişen doğasına odaklanılarak "yeni savaşlar" ve "postmodern savaş" olguları açıklanacaktır. Son olarak ise, ikinci bölümle ilişkili olarak Clausewitz'in savları mutlak savaş, üçleme (trinity), savaş-politika ilişkisi ve rasyonellik üzerinden eleştiriye tabi tutulacaktır.

\section{Clausewitz ve "Savaş Üzerine"}

Batının en büyük askeri kuramcısı olan Carl Philipp Gottlieb von Clausewitz (1780-1831), Napolyon'a karş1 savaşmış olmakla birlikte Napolyon'un askeri yeteneğinin hayranlarından ve yorumcularından en önemlisi olmuştur (Addington, 1994). Clausewitz ${ }^{1}$, 1818'de Prusya Harp Okulu Komutanlığı'na atanmış ve 12 yıl görevde kaldığı dönemde "Savaş Üzerine" isimli yapıtını şekillendirmiştir. Bununla birlikte "büyük deneyime sahip bir asker, tarihsel düşünen bir filozof ve politik bir teorici” olarak bilinen Carl von Clausewitz, 51 yaşında koleradan öldüğü için, 1832 yılında Vom Kriege'ın (Savaş Üzerine) düzenlenmesi ve yayımlanması eşi Marie von Clausewitz tarafından sağlanmıştır. Carl von Clausewitz'in Savaş Üzerine isimli eseri, M.Ö. 400'de Thukydides'in Pelopones Savaşı isimli eseri ile birlikte savaşın temel sorunlarıyla ilgilenen en

\footnotetext{
${ }^{1}$ Fransızlar tarafından Clausewitz'in keşfedilmesi, Fransızlarla Prusyalılar arasındaki savaşlarda Almanların saldırılarının dikkatli bir şekilde incelenmesi ile olmuştur (Irvine,1940: 158). İngilizler Birinci Dünya Savașı'nın arifesinde (Wallach, 1978: 126), Amerikalılar ise 1951'den sonra Clausewitz' in önemini kavramışlardır (Hahlweg, 2008: 768).
} 
büyük askeri-teorik eser olarak kabul edilmektedir (Oetinger, Ghyczy ve Bassford, 2001: 17,22).

Savaş Üzerine; iki cilt ve her bir ciltte 4 kitap olmak üzere toplam 8 kitaptan oluşan bütüncül bir eserdir. Yazar klasik devletler savaşını paradigmatik biçimde ele alıp analiz etmektedir. Savaşı bizzat yaşamış, asker psikolojisi ve deneyimi bulunan Clausewitz (2008) bu eserinde; savaş üzerine geliştirdiği kuramları ve stratejileri savaş teorisi, savaş sanatı ve savaş tarihi bağlamında ele almıştır.

Metod olarak parça ile bütünü birlikte ele alan Clausewitz'in (Williams, Wright ve Evans, 2007: 202) metodolojik yaklaşımının gerçeklik ve ideal arasındaki mantıksal yorumlaması teori, tecrübe ve gözlem çalışmalarının birleşimine ihtiyaç duymuştur. Politikanın önceliği, savaşın araçsallaştırılması ve hırs, akıl ve şans gibi savaşın üçlü yapısı Clausewitz tarafından çok önemli bulunmuştur (Kaldor, 2010: 271-272).

Clausewitz'de iki temel savaş tanımının varlığı göze çarpmaktadır. Clausewitz savaşı hem "düşmanı irademizi kabule zorlamak için bir kuvvet kullanma eylemi” hem de "sadece politikanın başka araçlarla devamı" olarak görmektedir. Dolayısıyla politik ilişkinin bir devamı olarak görülen savaş araç, politik niyet ise amacı teşkil eder (2008: 30,45-46). Bu iki tanımdan birincisinin "kullanılan yöntemlerin mantığına", ikincinin ise "savaşın amacına" işaret ettiğini savunan Vasquez’e (2015: 34-35) göre; savaş1 "siyasal bir zorlama eylemi" olarak gören Clausewitz'in anlayışında, duygusallığın siyasal amacın önüne geçmesine de izin verilmez.

Savaşı, "ciddi bir amaç için ciddi bir araç" olarak gören Clausewitz, savaşta uygulanabilecek amaçların en iyisi olarak "düşman silahlı kuvvetlerinin ortadan kaldırılmasını" görmüştür (2008: 44,63). Yine ona göre, savaş politik bir amaçtan doğar ve bu politik amaç zorba bir kanun koyucu değildir ve sonuna kadar savaşa yön verir. Diğer bir deyişle, savaş, bağımsız bir şey olmayıp, politik bir araç ve eylemdir. Savaşlar bunun yanı sıra kendilerini doğuran etkenlerin ve şartların niteliğine göre çok değişik biçimlere büründükleri içindir ki birbirlerine benzemezler (Williams, Wright ve Evans, 2007: 218-220).

$\mathrm{Bu}$ açıdan "savaş sanatından" ziyade "savaş bilimi" demenin daha uygun olacağını ama gerçek anlamıyla savaşın ne sanat ne zanaat ne de bilim olduğunu, savaşın insanlar arası bir ilişki biçimi olduğunu ve savaşı sanatla karşılaştırmaktansa ticaretle karşılaştırmanın daha iyi olacağını savunmaktadır. Çünkü Clausewitz'e (2008: 126128) göre, "ticaret de insanlar arasında bir çıkar ve faaliyet çatışmasıdır. Fakat savaş, politikaya çok daha yakındır; çünkü yasa arama ve bulma çabalarının nasıl devamlı yanılgılara yol açtığı, bu alanda daha kolay anlaşılmaktadır."

Savaş sanatının canlı ve moral güçlerle uğraştığı için hiçbir zaman mutlak ve kesin bir sonuç doğurmayacağını düşünen Clausewitz (2008: 36,43); savaşın tesadüfün (rastlantının), kaza ve bahtın (kaderin) en çok rol oynadığı faaliyet alanlarından birisi olduğunu, objektif ve sübjektif niteliği ile kumara benzediğini belirtir.

"İnsanlar arasındaki kavga, esas itibariyle düşmanlık duygusu ve düşmanca niyetten oluşur" şeklinde insan doğasının kötülüğüne yapılan vurgudan sonra daha genel olduğunu düşündüğü düşmanca niyetten hareketle açıklamasını yapan Clausewitz, savaşların duygulardan kaynaklanmasa bile az ya da çok duygunun etkisinde kaldığını düşünür. Bunun ise uygarlık düzeyinden ziyade düşmanca çıkarların önemine ve süresine bağlı olduğunu öne sürer. Çünkü ona göre; "savaş körü körüne bir ihtiras eylemi olmadığından aksine politik amaç ağır bastığından, bu amacın değerini, onu elde etmek için göze almaya hazır olduğumuz fedakârlıkların büyüklüğü belirler... O halde harcanan kuvvet, politik amacın değerine denk olamayacak kadar artar artmaz savaştan vazgeçilecek ve barış olacaktır" (2008: 31,51-52).

Clausewitz'i, klasik realizmin ${ }^{2}$ savunucularından Morgenthau ve Machiavelli ile kıyasladığımızda şunlar söylenebilir: Clausewitz, güvenliği Hans Morgenthau gibi diğer hedefler ve değerler için ön koşul olarak görse de Morgenthau'dan farklı olarak güç açısından anlaşılabilecek devletlerin çıkarı iddiası bulunmamaktadır. Machiavelli'nin ${ }^{3}$ politik anlayışına saygı duymakla birlikte rejim veya prens için şan ve şeref olarak çıkar tanımlamasını kabul etmemektedir. Clausewitz ayrıca Machiavelli'nin başarılı devlet adamının askeri uzman olması gerektiği görüşüne de katılmamaktadır. Clausewitz, karar alıcıların bilhassa karakteri güçlü ve seçkin akıllı kimselere ihtiyaç duyduğunu ve gerekli askeri bilgiyi bir şekilde veya diğer yollarla genellikle elde edebildiklerini ileri sürer. Machiavelli'nin devletin hayatta kalmak için genişlemek zorunda olduğu görüşüne katılmayan Clausewitz; savaşın sürdürülmesinin mümkün olduğunu kabul etmesine rağmen, şan ve güçle devlet çıkarlarını aynı kefeye koymamakta ve güç kullanımının mümkün olduğu görüşünü daha fazla sınırlamaktadır (Nielsen, 2007: 215).

Clausewitz, savaşı sınırı olmayan bir şiddet hareketi olarak görmekle birlikte ateşli silahların gelişimi ve uygarlığın ilerlemesinin savaşın üzerindeki düşmanı yok etme eğilimini ortadan kaldırmaya yönelttiğini belirtmektedir. Clausewitz, 1813-15 savaşlarında Napolyon'un kesin olarak yenilmesiyle kabile savaşları döneminin sona erip ulusal savaşlar çağının başladığını öne sürmektedir (aktaran Williams, Wright ve Evans, 2007: 204).

Clausewitz'in düşüncelerinin uygulanabilmesi için kitabın yazıldığı dönemde uluslararası sistemin istenilen aşamada olmaması, bir süre daha beklemeyi gerektirmiştir. Viyana Kongresi sonrası, Birinci Dünya Savaşı'na kadar olan dönemin ilk yarısında, savaş ve barış ile asker ve sivil kesin bir şekilde ayrilırken, 1860'lara gelindiğinde Avrupa'da artık savaş Clausewitz'in düşüncesine göre şekillenmiş,

\footnotetext{
${ }^{2}$ Realistler uluslararası politikada öncelikli aktörler olarak devletleri ele almaktalar (ve bu devletler hayatta kalmak için güç peşinde koşarlar) ve uluslararası ortamının karakteristiğini anarşi olarak tanımlamaktadırlar. Bu anarşi durumda, devletler arasında çıkar çatışmalarının çözümü için yüksek bir otorite bulunmamaktadır ve savaşların olasılığı hep mevcuttur. Clausewitz, realist düşüncenin bu tür temel ilkelerini barındırmaktadır. Clausewitz, güce başvurmada ulusun haklılığını sınırlandırmak için uluslararası hukukun yeterliliğini inkâr etmektedir ve ona göre güç, savaşın aracıdır (Nielsen, 2007: 213). Clausewitz'in öğretilerinin Marksist düşünürler üzerindeki etkisi için ise bkz. Gat, 1992: 363-364.

${ }^{3} 19$. yüzyılda ve 20 . yüzyılın başında herhangi bir uyuşmazlığı çözmek için masaya oturan diplomat sorunun çözülmemesi halinde savaşı son çare olarak kullanmıştır. Clausewitz'in bu dönem için geçerli olan tanımı örneğin, ondan yaklaşık üç asır önce yaşamış olan Machiavelli döneminde tam tersidir (Yalçınkaya, 2008: 33-34).
} 
yani araç olarak kullanılmaya başlanarak sınırlı ${ }^{4}$ olmaktan çıkmıştır (Yalçınkaya, 2008: 173-175).

\section{Savaşın Değişen Doğası: Yeni ve Postmodern Savaşlar}

\subsection{Savaşın Değişen Doğasi ${ }^{5}$}

Napolyon Savaşları sonrası Clausewitz'in altyapısını oluşturduğu ve 19. yüzyılda sanayinin gelişmesi ve orduların büyümesiyle oluşan topyekün savaş ${ }^{6}$ sonraki dönemde farklı bir boyut kazanmaya başlamıştır. Birinci Dünya Savaşı ile birlikte savaşlara hava boyutunun da dâhil edildiği, İkinci Dünya Savaşı sonrasında ise nükleer silahlanma yarışıyla oluşan yıpratma stratejileriyle artık savaşların büyük devletlerin arasında gerçekleşmediği bir yöne evrilmiştir (Yalçınkaya, 2008: 145). Son 30 yıla bakıldığında ise, en yaygın çatışma türünün devlet-içi çatışmalar olduğu görülmektedir (Pappila 2008: 71).

Örneğin Soğuk Savaş’ın bittiği 1991 yılından 2003'e yılına kadar, her iki tarafin devlet olduğu sadece on savaş (IrakKuveyt 1991-1994, Irak-ABD 1991, Sirbistan-KaradağHirvatistan 1991, Bosna-Hersek-Sirbistan Karadağ ve Hırvatistan 1992-1995, Hirvatistan-Sırbistan-Karadağ 1992-1995, Azerbaycan-Ermenistan 1992-1994, LaosTayland 1993, Eritre-Etiyopya 1998-2000, AfganistanABD 2001, Irak-ABD 2003) meydana gelmiştir. Günümüzde iç savaşların arttığı ve artık savaşlarda aktörlerden en az birinin devlet-dışı olduğu görülmektedir (Yalçınkaya, 2008: 35-37).

11 Eylül 2001'deki saldırıların yerini, İtalya Dışişleri Bakanı Franco Frattini'nin "diplomasinin 11 Eylülü" (Timeturk, 2010) olarak lanse ettiği Wikileaks belgelerinin alması, yani terör saldırısından diplomatik saldırıya geçiş

${ }^{4}$ 19. yüzyıla kadar savas meydanlarında yalnızca askerler bulunurken, 19 ve 20. yüzyıllarda özellikle Napolyon savaşlarında görüldügü üzere tüm ulusun askerleştiği bir sürece evrilmiş ancak 20. yüzyılın sonlarından itibaren sınırlı hale geri dönüș yapmıștır. Buna karșın son durumda medyanın bilgi aktarımı dolayısıyla toplumun savaşa ilgisi devam etmiştir (Yalçınkaya ve Türkeş 2008: 60). Richard Ned Lebow’a göre ise, siyasi liderler savaşın sınırlı kalmasını istemelerine karşın politik baskılar gibi nedenlerle savaş genişleyebilmektedir. Nitekim Birinci Dünya Savaşı, Almanya ve Avusturya tarafindan sınırlı bir savaş olarak düșünülmesine karşın Avrupa'yı ve Dünyayı saran bir savaş haline gelmiştir (1988: 82).

${ }^{5}$ Savașın doğasına ilişkin geleneksel tartışmalarda üç görüs ön plana çıar. Bunlardan birincisi, savaşlar çıktığında, siyasi hedeflerce kontrol edilemez olduğunu savunan ve bu nedenle askeri kaygılarla hareket edilmesini savunan militarist okuldur. İkincisi, savașın politik amaçlarla yürütülebileceğini savunan politik gerçekçilik okuludur. Üçüncüsü, savaşın kaçınılamaz bir gerçek olduğunu reddeden ve siyasi çatışmaları ve kararları belirlemek için alternatif bir felsefi bakış açısı sunan pasifist okuludur (Lider 1977: 188-192).

${ }^{6}$ Napolyon'un uygulamalarından hareketle topyekün savașın fikir babası olarak bilinen Clausewitz, oysa topyekün savaş yerine mutlak savaş kavramını kullanmıştır. "Topyekün savaş” kavramı, ilk kez General Erich Ludendorff tarafından yazılan Der Totale Krieg (Topyekün Savaş) isimli eserde kullanılmıştır. Erich Ludendorff'a göre ise topyekün savaş; ülke topraklarının ve halkının tamamının savașa girmesi, etkin bir propagandanın varlığı, savaş hazırlıklarının çarpışmalardan önce başlaması ve bir başkomutanın olması gibi beș temel unsur barındırmaktadır. Bu topyekünleşmede, 19. yüzyılda savaş, millet, ordu ve stratejilerin yanında Sanayi Devrimi sonrasında kullanılan modern teknikler etkili olmuştur. Ortaya çıkan bu modern savaşları eski savaşlardan farklı kılan bazı nitelikleri ise şöyle sıralanabilir: Mekanikleşme, oransal ya da miktar olarak askeri kuvvetlerin büyüklüğünün artması, tüm nüfusun askeri organizasyona girmesi, hükümetin ekonomiyi ve kamuoyunu kontrol etmesi, tüm modern silahların yıkıcılığının artması ile askeri harekâtta asker-sivil ayrımının ortadan kalkması, savașlarda askeri harekâtın yoğunlaşması (Yalçınkaya, 2008: 177-185). gibi örnekler, günümüzde savaşın artık karakterinde de değişim ve dönüşüm yaşandığını ortaya koymuştur (Hahlweg, 2008: 766-767). Dahası gelecekteki savaşların, kitle imha (nükleer, biyolojik ve kimyasal) silahlar yüzünden asimetrik olabileceği gibi her iki tarafin bu silahlara sahip olduğu durumlarda karşılıklı caydırmayı içeren bir simetrik yüzünün de olabileceği beklenmektedir (New 1996: 81). Bütün bu bilgilerden yola çıkılarak savaşın doğasının değiştiği ve daha da değişebileceği görülmektedir. Bu çalışmada savaşın değişen doğası yeni ve postmodern savaş olguları üzerinden incelenecek olmakla birlikte savaşın değişen doğasına pek çok yazarın ilgi duyduklarını, yaptıkları çalışmalarda savaşı farklı isimlendirebildikleri ve dönemlere ayırabildiklerini de hatırlatmak gerekir. $\mathrm{Bu}$ durumu özetler nitelikteki çalışmasında Gürcan (2014: 75-76) şu şekilde bir tasnif yapmaktadir:

- Lind, W.S., Nightengale, K., Schmitt, J.F., Sutton, J.W. ve Wilson, G. I.: 1. Westfalya öncesi savaşlar, 2. I. Nesil Savaş-Klasik (Napolyon) Savaşlar/1 (1648- 1830), 3. II. Nesil Savaş-Topyekûn Endüstri Savaşları (1830-1918), 4. III. Nesil Savaş-Manevra Savaşları (1918-1948) ve 5. IV. Nesil Savaş-Gayri-Nizami Harp Türevleri (1948'den günümüze).

- D. J. Hanle: 1. Ortaçağ Dönemi (Fiziksel Yetenekler), 2. Klasik Dönem (Grup Yetenekleri), 3. Erken Modern Dönem (Teknik Yetenekler), 4. Geç Modern Dönem (Sevk ve İdare Yetenekleri), 5. Nükleer Dönem (Sosyal Yetenekler).

- A. Toffler: I. Dalga: Tarım Toplumu, II. Dalga: Endüstri Toplumu, III. Dalga: Bilgi Toplumu.

- J. Arquilla ve D. Rondfelt: 1. Kılıç Dönemi, 2. Kitle ve Endüstri Savaşları Dönemi, 3. Manevra Savaşları Dönemi, 4. Birbirinden Türeyen Savaş Benzeri (Savaşımsı) Çatışmalar.

- M. V. Creveld: 1. Aletler Çağı, 2. Makineler Çağı, 3. Sistemler Çağı, 4. Otomasyon Çağı.

- Q. Liang ve W. Xiangsui: 1. Limitli/Sınırlı Ortaçağ Savaşları, 2. Limitli İmparatorluklar ve Ulus-Devlet Savaşları (Ör. 1991 Körfez Savaş1), 3. Limitsiz PostModern Savaşlar.

\subsection{Yeni Savașlar}

Savaş, "siyasi olarak çerçevelenmiş iki veya daha fazla örgütlü grup içeren bir şiddet eylemidir". Bu tanımın mantığına göre, savaş, Clausewitz'in tanımının ima ettiği gibi bir karşılıklı girişim olabileceği gibi, bir irade yarışması da olabilir. Karşılıklı teşebbüs, her iki tarafın savaş girişiminde bulunmak için diğerine ihtiyacı olduğu anlamına gelirken, istek ve iradenin işin içine girmesi düşmanın ezilmesi gerektiğine ve dolayısıyla savaşın aşırılık eğilimine vurgu yapar. Oysa Kaldor'un (2010: 274) üzerinde durduğu "yeni savaşlar", düşmana ihtiyaç duyulan ve belirli grupların yararlandığı bir savaş hali olmakla birlikte klasik/doğrudan savaşların nadir görüldüğü ve şiddetin daha çok sivillere yöneldiği savaşlardır. Soğuk Savaş'ın sona erişi ile vuku bulan Yugoslavya, Somali ve Ruanda'da meydana gelenler, yeni savaşlara örnek verilebilir. 
$\mathrm{Bu}$ durumun varlığı geleneksel savaş tanımlarında değişikliğe yol açmıştır. Örneğin, Eski Yugoslavya Savaş Suçları Mahkemesi (ICTY), "iki veya daha fazla hasım grup arasındaki silahlı kuvvetler vasıtasıyla gerçekleşen çatışma durumu" olarak tanımlanan genel savaş tanımını güncellemiştir. Buna göre savaş veya silahlı çatışmayı; "devletlerarasında silahlı güce başvurulduğunda veya hükümet güçleri ile organize olmuş silahlı gruplar arasında süregiden silahlı çatışma halinde veya bir devletin içinde bulunan silahlı gruplar arasında çatışma meydana geldiğinde oluşan durum" olarak tanımlamıştır. Yalçınkaya, da NATO'nun yaptığı savaş tanımındaki “...milli güçlerinin tamamını veya bir kısmını kullanarak yaptıkları..." ifadesinden yola çıkarak günümüz ordularının halen milli olmalarına karşın günümüz savaşlarının milli olmaktan çıkmaya başladığını hatırlatmaktadır. Ona göre, bu duruma istisna olarak gösterilebilecek ABD'nin Irak ve Afganistan Savaşları, aslında koalisyon güçlerince gerçekleşmesi sebebiyle, milli oldukları teknik olarak söylenemez (2008: 30-37).

Clausewitz'in tanımının kendi dönemi dışında geçerli olmadığını öne süren Yalçınkaya, günümüzde sorunları çözmek için masaya oturan diplomatın, NATO'nun savaş tanımı dikkate alındığında "...masa başında mesele hallolmazsa, o zaman savaşırız..." gibi lüks bir düşünceye sahip olmadığını belirtir. O, bu sebeple Soğuk Savaş yılları için geçerli olan "barış yolu ile halledilemeyen meselelerin halli için..." ifadesinin günümüz savaşları için geçerli olamayacağını öne sürer. Öyle ki yeni dönemde savaş kavramını, "hükümetlere bağlı veya hükümet oluşturmaya istekli meşru organize gruplar arasındaki büyük ölçekli şiddetli çatışma durumu" olarak tanımlamaktadır. Yine ona göre; Soğuk Savaş sonrası dönemin aksine tarih boyunca iç savaşlara sıklıkla rastlanmamasının da etkisiyle tarihsel çatışmalarda savaşlar incelenirken genellikle uluslararası savaşlar ele alınmıştır. Günümüzde ise devletler arası savaşlardan ziyade genellikle devlet içi çatışmalar yaşanmakta ve son yıllardaki savaşların zayıf ve problemli devletlerde cereyan etmesi, çatışmalarda devlet-dışı aktörlerin sıklıkla görülmesine sebebiyet vermiştir (Yalçınkaya, 2008: 32-40).

Kaldor'a göre de günümüz savaşlarının, 19. ve 20. yüzyıldakilerden farklı bir iç doğası vardır. Bu dönemdeki Avrupa savaşlarının aksine günümüz savaşları sonuçsuz, uzun süreli ve yayılma eğilimindedir (2010: 271). Münkler'e göre ise, 17. yüzyılın ortası ile 20. yüzyılın başlarındaki devletler arası savaşlar, bazı istisnalar dışında muharebenin $^{7}$ sonucu müteakip barış görüşmelerinin temelini oluşturan yani savaş ilanıyla başlayan barış anlaşmasıyla sona eren, belli kuralları ve zaman sınırı bulunmayan kısa savaşlardır (örneğin Birinci ve İkinci Dünya Savaşları). Oysa yeni savaşlar, gidişatı askeri güçlerin zaman ve mekâna yoğunlaştırılmasından ziyade dağıtılmasının belirlediği partizan savaş ilkelerine göre yürütülen, her yerde patlak verebilen, Clausewitz'in "savaşın can alıcı noktası" dediği nihai muharebeden yoksun çatışmalardır (Münkler, 2010: 26-27).

${ }^{7}$ A. Bilgin Varlık'a (2013:127) göre; muharebe, harekât, sefer, çarpışma, çatışma, askeri doktrin ve stratejiler gibi daha çok savaşma yöntem ve şekilleri ile savaşın alt unsuru niteliğindeki eylemlerin, savaş kavramı yerine kullanılması uygun değildir.
Yeni çatışma türleri; küçük, sınırlı veya düşük yoğunluklu olarak tanımlanabilmektedir. Bununla birlikte ana nokta, savaşın bir düşmanı yenmek için artık bir araç olmadığıdır. $\mathrm{Bu}$ savaşların iç eğilimi, sınırlar olmaksızın savaş değil, sonsuz savaştır. $\mathrm{Bu}$ şekilde tanımlanan savaşlar, siyasi kimliği çoğaltmak ve daha fazla ekonomik çıkar sağlamak için kendi kendine sürekli olarak paylaşılan bir ilgi oluşturmaktadır. Bu da yeni savaşların varlığına daha fazla ilgi gösterilmesini beraberinde getirmektedir (Kaldor 2010: 274-275).

\subsection{Postmodern Savaş}

Postmodern savaş olgusuna yönelik birisi doğrudan (Gray) diğeri ise dolaylı (Hardt ve Negri) iki bakış açısı sunmak mümkündür. Günümüzde yeni bir barış ve savaş dönemine girildiğini söyleyen Chris H. Gray kitle imha silahlarının bir yandan bilimsel ve teknik gelişmelerle hızla yayılarak devlet-dışı aktörlerin eline geçtiğini, diğer yandan da iletişim, ekonomik bütünleşme ve barış güçleri sayesinde bunların denetim altına alınabildiğini söylemektedir (2000: 25).

Enformasyonun yeni bir savaş yöntemi olduğunu düşünen Gray (2000), Clausewitz'den ziyade Foucault'a yakın durarak "savaş, politikanın bir biçimidir" demektedir. Ayrıca "postmodern modaya uygun olarak savaş; barış için yapılmaktadı" der. Gray, postmodern savaşla; 1500'lerden 1950'lere (ancak daha belirgin olarak 1990'lara) kadar yürütülen klasik savaş araç ve tekniklerinden farklı olarak enformasyona dayalı siber savaş (info-savaş) ve bilgisayar teknolojilerinin kullanılmasını kastetmektedir (aktaran Veysal, 2010: 263-264).

Buna göre, modern savaş, 500 y1l önce ulus devletlerin keşfi, akılcılığın zaferi ve Avrupa sömürgeciliğinin yayılması ile kendine alan açmıştır. Avrupa sömürgeciliğinin çöküşü, ulu-devletlerin zayıflaması ve indirgemeci akılcılığa eleştiri ise postmodern savaşla çakışan gelişmeler olmuştur. Gray’e göre, bu modern savaş, 1980'lerin sonuyla birlikte günümüz çatışma durumunu yansıtan postmodern savaş karşısında tamamen yok olmasa da çöküşe geçmiştir (2000: viii-ix).

Gray; sürekli, teknolojik, hayali, sonu olmayan, siber, hiper-modern, altıncı kuşak savaş gibi pek çok şekilde ifade edilebilen yeni savaşlar için postmodern savaş kavramını tercih etmektedir. O, savaşı doğal bir dürtü ve kaçınılmaz olarak görmediği gibi bu yönde görenlerin bile nihayetinde savaşa bir son verme noktasında kesiştiklerini söyler (2000: xxii, 26).

M. Hardt ve A. Negri'nin ${ }^{8}$ (2004) küresel egemenliğin özelliklerini belirlemeye çalıştıkları "İmparatorluk"ta ise,

\footnotetext{
${ }^{8}$ Hardt ve Negri'nin imparatorluğu; karma bir kuruluş yapısına sahip, merkezi, iktidarı ve dışarısı olmayan yani herkesi kapsayan bir imparatorluktur. Bu üç kavramla, ilk olarak, yerelden küresel ölçeğe kadar "bir dizi yapının birbirleriyle uyumlu olacak şekilde bir araya gelmesinden oluştuğu", ikinci olarak, küreselleşme şemsiyesi altında finans, kültür, turizm gibi pek çok merkezden oluştuğu, üçüncü olarak, imparatorluğun tüm dünyayı kapsaması hasebiyle imparatorlukta olup bitenlerden herkesin etkilenmesi kastedilmektedir. Hardt ve Negri’ye (2003) göre bu imparatorluktan kurtulmanın yolu da yine imparatorluğun içindeki çoklukla olabilecektir. Otonomi ve demokrasiyi başarma kabiliyetine sahip etkin bir çok boyutluluğu (homojenleştirici özelliğe sahip halktan ayrılır ve güruh, kalabalık gibi edilgenliğe işaret etmekten ziyade etken bir kavramı) içeren çokluk, imparatorluğa alternatif olarak sunulmaktadır (aktaran Şahin, 2008: 57-58).
} 
hem savaş hali kaçınılmaz hem de yönetim biçimi imparatorluğa özgü olarak görülmektedir. Demokrasilerin askıya alındığı savaş durumları, güçlü merkezi otoritelerin ortaya çıktığı iktidar yapılarını beraberinde getirir. Onlara göre, günümüzde savaş, "küresel iktidarın sürekli ve küresel bir uygulamasına dönüşmüştür”. Yapılan her savaş, küresel iktidarca yürütülen dünyayı egemenliğine alma mücadelesidir. Ama aynı zamanda bu egemenliğe karşı çıkmanın ve demokrasinin bir parçası olarak sayılabilecek bir mücadelenin ürünüdür. Bunun yanı sıra savaş; nüfusu kontrol etmeyi ve toplumsal yaşamı (yeniden) üretmeyi hedefleyen bir yönetim biçimi öngörür ki bu savaşı bir biyoiktidar rejimi haline dönüştürür. $\mathrm{Bu}$ ise savaşın ölümcül yönü ile yaşamı üretme arasında bir dikotomi oluşturur. Böylelikle savaş, iktidarın eylemlerinde normalleşen bir durum arz eder (aktaran Veysal, 2010: 257-258).

\section{Clausewitz'e Eleştiriler}

\subsection{Mutlak Savaş ve Üçleme Üzerine Eleştiriler}

Prusya ve Almanya'nın ahlakında bir rejenerasyon oluşturacağını umduğu için halk savaşını kısa süreliğine de olsa coşkuyla savunan Clausewitz, halk savaşına karşı yöneltilen eleştirilere büyük ölçüde katılmaz. Clausewitz halk savaşının devletler savaşının aksine asimetrik bir yapıda olduğunu belirtmektedir. Lakin Münkler; 1813'teki Napolyon karşı1tı kurtuluş savaşını ve 1870-71'deki AlmanFransız Savaşı'nı ve III. Napolyon'un istifasından sonra iktidara gelen cumhuriyetçi hükümetin düzenli birliklerin ağır yenilgisini telafi etmek için tüm halkı 1793 'te seferber etmesini, asimetrik savaş niteliğinde görmez. Zira bu savaşlar ters yönde eğilimler olmasına karşın, muharebe alanında sonuçlanmıştır (2010: 116-117). Simpson'a göre de Prusya'nın bir denizaşırı imparatorluğa ya da herhangi bir ciddi deniz gücüne sahip olmadığı göz önünde bulundurulduğunda, Clausewitz'in Avrupa savaş deneyiminin büyük bir kısmı hakkında hiçbir şey söylemediği göz önünde bulundurulmalıdır (2017: 13).

Savaş türleri, Clausewitzçi modelde üç temel kavramla başlar: Sınırlı, total ve mutlak savaş. Clausewitz, mutlak savaşı, şiddetin mantıksal bir sınırının olmadığ olarak görmektedir (aktaran Sharma 2015: 334). Kaldor ise gerçek savaşın, Clausewiz'in sürtünme ${ }^{9}$ (friction), direnç (resistant ) ya da iletken olmayan ortam (nonconducting medium) olarak adlandırdığı mutlak savaştan farklılık arz ettiğini belirtmektedir (Kaldor 2010: 272-273).

Savaş Üzerine hakkında yöneltilebilecek eleştirilerden bir tanesi günümüz savaşlarının artık Clausewitz'in devletler savaşının en önemli özelliği olarak gördüğü nihai muharebenin günümüz savaşlarında artı pek yaşanmadığına yöneliktir. Münkler'in kitabıyla aynı adı taşıyan yeni savaşlarda ayrıca, savaşın izleklerinin birleştiği ve kararın verildiği yer ve zaman da yoktur (Münkler, 2010: 27-28).

\footnotetext{
9 Clausewitz'in savaşın hızını yavaşlatan her şey olarak tanımladığ sürtünmenin en büyük biçimi siyaset/politikadır. Clausewitz'e göre, sorumlu olanlar, savaşın ne zaman yapılacağına, ne zaman ara verileceğine ya da tamamen durdurulacağına siyasi olarak karar verirler. Bu siyasi kararlar komutanın kontrolünün dışında kaldığı için ek bir sürtüşme kaynağıdır (aktaran Creswell 2011: 105).
}

Simpson'a göre, Clausewitz savaşın soyut doğasından bahsetmekte ve diplomasi ve diğer şiddetsiz araçların daha fazla rol oynayabileceğini ihmal etmektedir. Örneğin Rusya ve pek çok devlet tarafindan "karma savaş/hybrid warfare" yöntemlerinin izlenmesi ve bu bağlamda ekonomik yaptırımlar ve siber kaynaklar gibi şiddetsiz araçların kullanılması gerçeği göz önüne alındığında bunların Clausewitz'in soyut savaş tanımında dikkate alınmadığı görülmektedir. Clausewitz'in savaş açıklaması, birleşik varlıklar arasındaki iki yönlü bir askeri savaşı tanımlar. Bu birleşik varlıklar, devletin parçaları olarak yani hükümet, halk ve ordudan oluşan üçlemeyi ifade eder. Clausewitz isyanı düşünürken bile, isyancıların kendi devletleri adına savaşacağını varsaymıştır. Oysa bir devlet-dışı aktör, birleşik bir varlık olarak görülmedikçe bu Clausewitz'in soyut savaş tanımına girmez (2017: 11).

Kaldor'a göre, 11 Eylül'de ortaya çıktığı gibi, devlet-dışı küçük gruplar bile kitlesel imha olaylarına neden olabilmektedir. Yine koalisyon güçlerinin Irak'taki ve Afganistan'daki veya İsrail'in Lübnan ve Gazze'deki askeri müdahaleleri, herhangi bir tarafin belirleyici bir avantaj kazanmasının zor olduğunu göstermiştir. Bu savaşlar, iki taraflı dolayısıyla karşılıklıdır. Bir taraf, diğerinin davranışının üzerinden kendisini haklılaştırmaya çalışmaktadır. Fakat bu karşılıklı davranışın mutlaka mutlak savaş eğilimi göstermediği gibi müdahale gerekçesi bakımından ahlaki sorgulamaya da açı olduğu hatırlatılmalıdır. Çağdaş Clausewitz eleştirilerinin çoğu, mutlak savaş kavramını ele almadıkları gibi devletin rolüne ve savaşın enstrümantal karakterine odaklanmaktadırlar. Örneğin John Keegan ve Martin van Creveld, hükümet, ordu ve halk üzerine inşa edilmiş üçlü savaş kavramının artık geçerli olmadığını öne sürmektedirler (Kaldor 2010: 274-276).

Buna karşın bu üçleme Clausewitz'de önemli bir yere sahiptir ve bu üçlemeyi birleştiren bir unsur olarak da savaş görülür. Clausewitz, savaşın, üçlemeyi birleştirerek ve ortak bir nedenden ötürü insanları harekete geçirerek, ulusu inşa ettiğini savunur. Oysa Kaldor, günümüz savaşlarında Clausewitz'in halk, ordu ve hükümet üçlemesinin yerini akıl, şans ve hırs (reason, chance and passion) şeklindeki üçlü motivasyon aldığını düşünmektedir (Kaldor 2010: 271,277).

Günümüzde flu hale gelen dost-düşman ayrımında olduğu gibi (Oetinger, Ghyczy ve Bassford, 2010: 47) Clausewitz'in hükümet, ordu ve halk arasındaki ayrımı da pek çok yeni savaşta flu yani bulanık hale gelmiştir. Yeni savaşlar, devlet-dışı aktörler ve devletin ağları tarafindan yürütülmekte ve sivil ve savaşçı arasındaki ayrım genellikle zorlaşmaktadır. Güvenlikle ilgili görevlerin üstlenildiği özel anlaşmalı çok sayıda tarafin bulunduğu ABD'nin Irak ve Afganistan'daki güçleri bu durumu doğrulamaktadır. Bu durum talan ve sınır dışı edilen nüfusun sorumlusu olarak görülen suçluların ve düzensiz çetelerin takip edilmesinde düzenli güçlerin belirmesi, 2008 Ağustosundaki Gürcistan'ın Rusya tarafından işgalinde de doğrulanmıştır. Yine Kaldor'a göre, Clausewitz'in savaş teorisi gerçekçi bir teori olarak görülse bile devletlerin birbirine bağlılığının savaş olasılığını azaltacağına inanması noktasında da eleştiriye tabidir (2010: 277,279).

Martin van Creveld, Clausewitz'in savaş anlayışına tamamen karşı çıkan ve Clausewitz'in savaş kuramının 
geçerliliğini yitirdiği için bu kuramı reforme etme çabalarının yersiz olduğunu düşünen görüşün önde gelen savunucularındandır. Postmodern savaş teorisyenlerinden olan ve devletin siyasi bir organ olarak işlevini yitirdiğini düşünen Creveld'e göre, "savaşın politikanın bir devamı" olarak görülmesi, 21. yüzyıl koşullarıyla örtüşmez. Çünkü Clausewitz'in halk, ordu ve hükümet üçlemesinden oluşan güç birliği, küreselleşen dünyada yerini devlet-dışı aktörlere, postmodern ve serbest piyasa ilişkisine uyumlu toplum düzenine terk etmiştir. Yine Creveld'e göre, yeni kuşak savaşlarla birlikte Clausewitz'in “araçlar amaçların devamıdır" söyleminin yerini araçlarla amaçların aynı olduğu savaş hali almıştır. Bu çerçevede savaşlar, daha ziyade köktendincilik gibi ideolojik bağlamda ya da insani müdahale gibi adaleti tesis etme amacıyla gerçekleştirilir hale gelmiştir (aktaran Oyan Altuntaş, 2008: 209-210).

Clausewitz'e göre, silahlı kuvvet kendi doğası ve politik amaç için olanların dışında hiçbir kurala tabi değildir. Savaşın en az şiddetle sınırlandırılabileceğini düşünmediği gibi savaş gibi tehlikeli şeylerde, nezakete de yer olmadığ kanısındadır. Clausewitz, savaş hukukunun "kendinden empoze edilen kısıtlamalarından" bahsetmeye gerek olmadığını belirtmiştir. Uluslararası hukukun bütününü ve geleneğini reddeden ${ }^{10}$ bu görüşe Creveld karşı çıkmaktadır. Çünkü ona göre savaş, saf dizginsiz bir güç olmaktan uzak kültürel bir faaliyettir ve her zaman diğerlerinin yanı sıra mahkûmlara, savaşçı olmayanlara ve silahlara ilişkin sınırlamalara maruz kalmıştır (Creveld, 1991: 404).

Creveld, gelecekteki savaşların, devletler arasında olmaktan çok devletler içinde düşük yoğunluklu çatışma şeklinde cereyan edeceği görüşündedir. Gerçekten de Soğuk Savaş sonrası dönemde devlet içindeki çatışmalar devletler arasındakilere göre önemli bir yer tutmuştur. Yine Clausewitz teorisinin kilit bir özelliğgi olan hükümet, ordu ve halk arasındaki üçleme, artık savaşı anlamada yararlı bir çerçeve sağlamamaktadır. Dahası, üçleme unsurları, devletdışı örgütler ve hatta bireyler de dâhil olmak üzere her şekilde stratejik aktörlerde bulunan niteliklere işaret eder hale gelmiştir (Stone 2007: 282,293). Bugün, siviller ve savaşçılar arasındaki ayrım hayati önem taşımaya başlamıştır. Siviller veya "halk" olarak bilinen savaşçı olmayanlar, savaştan etkilenenlerin büyük çoğunluğunu oluşturmaktadır (Creveld, 1991: 410).

Clausewitz; birincisi, siyasal amaçlar ve mantıksal çıkarımlar, ikincisi, tesadüf ve olasılık hesapları ve üçüncüsü, şiddet, kin ve nefret olmak üzere savaşlarda üç eğilim görüldüğünü ve bunların da sırasıyla hükümet, ordu ve halka hitap ettiğini belirtmektedir. Onun savunduğu halk, ordu ve hükümet arasındaki ilişkilerin dengeli olması gerektiği tezi, günümüzde özellikle halkın ordu ve hükümeti denetleme rolü nedeniyle eleştiriye maruz kalmaktadır. Hükümet-dışı kuruluşların yanı sıra çağdaş demokrasilerde seçim yoluyla ve gelişmiş kitle iletişim aracılığıyla halkın hükümet ve ordu üzerinde baskı kurduğu öne sürülmektedir. Bunu önlemek için hükümet ve ordunun, medyanın ve hükümet-dışı kuruluşların

\footnotetext{
${ }^{10}$ Clausewitz, pozitif hukukla ilgili moralitenin kıyaslanması bakımından Thomas Hobbes'u takip ettiği görülmektedir (Nielsen, 2007: 213). Buna karşın Smith (1994: 137-138), her ne kadar Clausewitz'in adil savaş kavramını açıkça reddetse de onun ahlaki askeri filozof olduğunu düşünmektedir. Onu bu görüşe yönelten en önemli neden ise Clausewitz'in savaşın öldürücü tehlikesini bilmesidir.
}

faaliyetlerini kontrol altına alma girişimleri olabilmekte ve böylece yeterince bilgilendirilmeyen halkın yanlış yöne sevk edilebilmesi mümkün olabilmektedir (Yalçınkaya ve Türkeş 2008: 59-60).

Dolayısıyla Clausewitz'in üçlemesinin günümüz savaşlarındaki yeni unsurlardan etkilenmesi söz konusudur. Örneğin Yalçınkaya ve Türkeş'e göre ${ }^{11}$; medya, özel askeri şirketler ve hükümet-dışı kuruluşlar savaşın dengesini etkileyebilecek devlet-dışı unsurlardır. Dolayısıyla hükümet-dışı kuruluşlar, medya ve özel askeri şirketler son dönemdeki faaliyetleri ile öne çıkarken, bunların Clausewitz'in döneminde öngörülmeyen yeni durumlar olduğu söylenebilir (2008: 55,84).

\subsection{Savaş-Politika İlişkisi ve Savaşın Rasyonelliği Üzerine Eleştiriler}

Günümüz savaşlarının çoğunda savaş cümlenin öznesi haline gelmiştir. Clausewitz'in Napolyon Savaşları'nın etkisiyle savaşa en azından metaforik anlamda bir özne rolü atfetmesi göz ardı edilirse, savaşı, politikanın bir aracı olan nesne olarak gördüğü söylenebilir. Oysa Münkler'e göre savaş, kendini politikanın bir aracı olan nesne konumundan kurtarıp politikanın yerini almıştır. Ayrıca yeni savaşlar kendi kendini yönetirken, savaşan taraflar yönetilir (Münkler, 2010: 60-61).

Clausewitz; savaşın kendi yasalarını ve mantığını izlediği görüşüne, şiddetle karşı çıkmakta ve savaşın elbette kendi gramerine sahip olduğunu ama kendine ait bir mantığ olmadığını dile getirir. Münkler ise; Klaus Jürgen Gantzel'in 1987 tarihli ve "Tolstoi stat Clausewitz?" isimli makalesinde de tartışıldığı üzere Clausewitz'in düşüncelerinin ampirik olarak doğrulanıpdoğrulanamadığından ziyade onun "savaşın, politikanın başka araçlarla sürdürülmesi” olduğu tespitini, yeni savaşlarda ancak bazı istisnai durumlarda ki o da diş güçlerin müdahalesiyle olabileceğini dile getirir. Diğer bir deyişle yeni savaşların siyasi bir çizgide seyretmediğini yani siyasi bir hedefin pek görülmemesi nedeniyle gerçeği pek yansıtmadığını zira genelde böyle bir çizginin kalmadığını belirtmektedir. Dolayısıyla Münkler'e göre;

\footnotetext{
${ }^{11}$ Basın kuruluşları; günümüzde özellikle $\mathrm{CNN}$ etkisi ve haber yönetimi ile dış ilişkiler ve savunma üzerinde etki kurmaktadırlar. Bunlardan haber yönetimi, basın kuruluşları aracılığıyla hükümetin haberleri kontrol altında bulundurması iken, $\mathrm{CNN}$ etkisi ise medyanın hükümeti etkilemesidir. Birincisine, ABD'nin Vietnam savaşı sonrasındaki politikası, ikincisine ise önce Somali'deki insani duruma dikkat çekerek buraya ABD askerlerinin gönderilmesi, yine 3 Ekim 1993'te 18 ABD askerinin öldürülmesi ile bu kez Amerikan askerlerin geri çekilmesinin sağlanması örnek olarak verilebilir. Günümüzde askeri birliklerin üstlenmiş oldukları roller, bunların hükümet-dışı kuruluşlarla arasındaki ayrımı flu hale getirmektedir. Çünkü söz konusu askerler sadece savaşmayıp, insani yardım, barışı koruma ve barış inşası gibi faaliyetleri de üstlenmektedirler. Söz konusu hükümet-dışı kuruluşlar ayrıca Clausewitz'in üçlemesindeki halka, ordu ve hükümeti denetleme kabiliyeti kazandırmak suretiyle zafer ve istikrar için gerekli olan dengenin bozulmasına sebep olabilecek niteliktedir. Hükümet-dışı kuruluşlar gibi Clausewitz zamanında öngörülmeyen bir etkiye mazhar olan başka bir unsur özel askeri şirketlerin varlığıdır. Clausewitz'in üçlemesindeki dengeyi bozucu özel askeri şirketler aslında tarihi süreçte örnekleri bulunan paralı askerliğin yeni bir motifi olarak görülebilir. Devlet ordularına bağlı olmayan, milli güvenlik için ikincil önemdeki görevleri yerine getirmesi ve böylece profesyonelleşmenin sağlanması için Soğuk Savaş sonrası canlanan bu sektörle birlikte her vatandaş için milli bir görev olan savaş, devletlerin ücret karşılığında elde etikleri bir hizmet şekline dönüşmüştür (Yalçınkaya ve Türkeş 2008: 62-63,71-74).
} 
yeni savaşların kendine ait bir grameri ve mantığı vardır (2010: 61-63).

Yeni savaşlar, başka yollarla siyasetin devamıdır. Fakat onlar politikadan ziyade siyasetle ilgilidir. Bunlar belirli bir politika hedefine ulaşmaktan ziyade siyasi seferberlik veya manipülasyonla ilgilidir. Kaldor'a göre; pek çok yeni savaş, dinsel ya da etnik kimlik politikaları üzerinedir. Dahası bu kimlikler çoğu kez savaş vasıtasıyla inşa edilmektedirler. Clausewitz için savaşın amacı dış politika ve politik eylemin aracı iken yeni savaşlar bunun tam tersidir. Yeni savaşlar, insan hakları hukuku ve savaş geleneğinin oluşturulduğu 1945 'den beri bu iki faktörü kasten ihmal etmektedir (Kaldor, 2010: 278-279).

Horst Afheldt, "Barışta Savunma: Askeri Araçlarla Politika" isimli ve "Clausewitz savaşı" konseptinin çöktüğünü iddia ettiği çalışmasında şöyle demektedir; "Clausewitz'in o zamana kadar geçerli olan bu konseptini SSCB ve ABD tamamen çökertti...Sovyetler'in 1957'de Sputnik'i uzaya göndermesiyle Clausewitz'in kesin sonuçlu savaşı, artık süper devletler arasında politikanın aracı olarak kullanılamaz hale geldi" (aktaran Hahlweg, 2008: 775).

Savaş-politika ilişkisi bağlamında Clausewitz'e eleştiri getirenlerden birisi de Michel Foucault'tur. "İktidar mekanizması, temel ve asal olarak baskıdır" ve "iktidar, savaştır, başka araçlarla sürdürülen savaştır" şeklinde iki temel varsayıma sahip olan Foucault, Clausewitz'in mottosunu tersine çevirerek "politika, savaşın başka araçlarla sürdürülmesidir" demektedir ve bu ona göre üç anlam taşır. Birincisi, iktidar ilişkileri, tarihin belli bir döneminde savaş yoluyla tesis edilen belli güç ilişkilerini yansıtır. Burada siyasal iktidar, bu güç ilişkisine süreklilik kazandırmak, yeniden kurmak, insanlara kurumlar, ekonomi ve söylemler vasıtasıyla işlemek için adeta sessiz savaş yolunu seçer. Bu ise siyaseti, "savaşta beliren güçler dengesizliğinin onayı ve sürdürülmesine" işaret eder. İkincisi, iktidar yapısını değiştirmek isteyenlerin çıkaracağı çatışmalar da yine savaş tarihinin bir parçası olarak değerlendirilmelidir. $\mathrm{Bu}$ durumda barışın tarihi aslında savaşın tarihi olmaktadır. Üçüncüsü, silahların yargıç olduğu, nihai kararın savaşla ortaya çıktığı bir çıkarımda da bulunabilir. Diğer bir deyişle, politikanın sonunu "son muharebe getirecektir" ki bu devam ettirilen bir savaş olan iktidar yapılanmasının askıya alınması anlamına gelir (2018: 31-32).

Siyasetin başka araçlarla sürdürülen savaş olduğu tezinin, Clausewitz'den önce de var olduğunu öne süren Foucault ayrıca bu tezin tarihsel bir paradoks taşıdığını iddia eder. Şöyle ki, Ortaçağdan modern çağın başlangıcına kadar devletlerin yükseldiği ve geliştiği bir süreçte savaş uygulamaları değişim geçirmiştir. $\mathrm{Bu}$ dönem, savaş uygulamalarının ve kurumlarının merkezi bir iktidar elinde toplandığı dolayısıyla "savaşın devletleştirilmesi” sürecini yansıtır. Dahası bu dönem; insanlar, topluluklar ve gündelik bir olgu olarak algılanan “özel savaş”tan kopuşu da yansıtır. Devletlerin sınırlarına itilmiş olan bu tarihsel-siyasal söylem 16. yüzyılın iç savaşlarının ve din savaşlarının sona ermesinden sonra meydana gelmiştir. $\mathrm{Bu}$ söyleme göre, barış, hukuk ve yasalar savaşların ürünüdürler. Savaşlar sonrası yapılan bırakışma veya zaferler kesin bir sonuç olarak görülmemelidir. Bunlar iktidar merkezinin bastırması ile devam etmektedir ki bu yüzden nihai savaş henüz kazanılmamıştır. Çünkü barış ortamlarında aslında savaş sürekli biçimde toplumun her kesimine sirayet etmekte ve böyle bir durumda ise tarafsız kalan olmadığ gibi mutlaka birinin düşmanı olduğunuz bir tablo ortaya çıkmaktadır (Foucault, 2018: 60-62).

İște bu noktada Foucault'a göre; devlet aygitları, yasa ve iktidar yapılarının düşmanlara karşı bizi korumadığı gibi bizi uyruklaştırma için kullandıkları bir ortamda "kendimizi topluma karşı savunmalıyız" söyleminin yerini "kendimize rağmen oluşturmakta olduğumuz öteki, alt ya da karşı ırkın getirdiği bütün biyolojik tehlikelere karşı toplumu savunmalıyı" almalıdır (2018: 73-74).

Clausewitz'in penceresinden diplomasi ve siyasetin işe yaramaması durumunda ihtilaf yaşayanlardan birisi karşı tarafi kendi iradesini kabul etmeye zorlayacaktır. Vasquez'e (2015: 35-36) göre; bu zorlama "egemenler arasındaki son çareyi", savaş ise "zorlamanın en aşırı biçimini" yansıtır. Böyle bir durumu Clausewitz (2008: 32) şu şekilde izah etmektedir: "Eğer düşmana kendi irademizi kabul ettirmek istiyorsak, onu kendisinden beklediğimiz fedakârlıktan daha sakıncalı bir duruma sokmamız gerekir".

$\mathrm{Bu}$ noktada savaşın, zorlamanın sadece özel bir çeşidi olduğu vurgusu yapan Vasquez, zorlamanın ancak yegâne ve en etkili yol alarak görüldüğü durumlarda savaşa götüreceğini söyler. Oysaki savaşın siyasal araç olarak kullanımından daha fazla yönü olduğunu düşünen Vasquez, kontrolü zor, daha eski ve derin bilinçsiz nedenlere dayanabilen şiddet kullanımının onun araçsallığından kaynaklanıyor olabileceği uyarısında bulunmaktadır. Vazquez'e (2015: 37) göre; Clausewitz'in savaşın amacını ön plana çıkarmaya çalışması, aslında savaşın kontrolünün zor bir olgu olduğunu ve rakibe hükmetmenin kendisinin bir amaca dönüşebileceğini, bunun da savaşı irrasyonel kılabileceğine yönelik endişeyi belli ölçüde Clausewitz'in de taşıdığını gösterir.

Bununla birlikte, Clausewitz'in şiddetin "sınırlı ve zorlayıcı" biçimde kullanılabileceğine ve savaşa rasyonel bir araç olarak bakmasına, Freud gibi modern psikologlar eleştiri getirmektedirler. Bunlara göre, siyasal amaçlardan ziyade başta aşırı düşmanlık olmak üzere dolduruşa gelme, çaresizlik, saldırganlık gibi ruh hallerinin yansıması da savaşın çıkmasında etkili olabilmektedirler. Örneğin, Freud (1930) savaşı, "modern medeniyetin artan psikolojik baskılamalarına karşı bilinçaltının patlayıcı bir tepkisi" olarak görür (aktaran Vasquez, 2015: 37-38).

Geleneksel savaş düşünürlerinin akıl alanı (mantık, plan) ile doğa alanı (daha çok şans ve insan iradesiyle açıklanan) arasında bir ayrıma gittikleri tespitinde bulunan Gray ise, bu ayrımın Clausewitz'in dediği "ikircimi"12 oluşturduğunu söyler. Clausewitzçi perspektifte kâğıt üzerindeki savaşla gerçek savaşı ayıran bir kavram olan ikircimi irade çözer. Gray'e göre; ikircimin yanı sıra moral, kahramanlık ve sezgiyi savaş alanına taşıyan isim olmakla birlikte iki dünya savaşı, Clausewitz'in kuramını ve modern savaşı zora

12 Gray; Sun Tzu'nun savaşta 5 temel unsur olarak gördüğü moral (duygusal), doktrin (mantıksal), komuta (mantık ve duygu), arazi ve hava koșullarının modern savaş tarihi boyunca farklı adlarla anılsa da bunların bir denge halinde kaldıklarını, bu dengenin savaşı bir bilim olarak değil de sanat olarak görülmesini sağladığını söyler. Yine Gray; akılcılığın her dönem başarılı bir savaş için elzem görüldüğünü ancak bunun yanında örneğin Sun Tzu'nun morali, N. Machiavelli'nin şansı, M. Janowitz'in kahramanlı̆̆ı, T.E. Lawrence'in ruhu, F. Kane'nin sezgiyi, Clausewitz de ikircimi öne çıkardığını belirtir (2000: 122). 
sokmuştur. Ona göre her ne kadar Clausewitz akılcı ve dengeli bir filozof olsa da savaşa aşırı istekli olması ile savaşı akılcı açıklama uğraşı çelişmektedir (2000: 122123).

\section{Sonuç}

Clausewitz'in savunduğu düşünceler, savaşla ilgili konulara ilgi duyan geniş bir kesimi etkisi altına almıştır. Halk, ordu ve hükümet üzerine inşa ettiği üçleme kavramı ve savaşlapolitika arasında bağlantı kurması yanında savaş tarihini ve savaş sanatını yorumlayabilmede Clausewitz'in önemli katkıları olmuştur.

Tüm bu olumlu etkilerine rağmen bu çalışmada yapıldığı üzere, Clausewitz'in eserinde ortaya koyduğu düşünce perspektifi önemli eleştiriler almaktadır. Her şeyden önce, günümüz dünyasında devletler arasındaki savaşlardan ziyade devlet içi çatışmaların artmaya başladığı hatta bunun vekâlet savaşlarıyla alevlendirildiği yeni bir süreç yaşanmaktadır. Gray'in postmodern, Kaldor ve Münkler'in yeni savaşlar dedikleri ve özünde savaşın doğasındaki değişime yapılan vurgu, Clausewitz'e yönelik önemli bir eleştiri kapısını araladığı söylenebilir. Söz konusu savaşın değişen doğası üzerinden Clausewitz'e yöneltilen eleştirilerin odağını ise, onun da savlarının merkezinde yer alan savaşın mutlaklığı, üçleme, savaş-politika ilişkisi ve rasyonelliğin oluşturması şaşırtıcı olmasa gerektir.

$\mathrm{Bu}$ bağlamda yöneltilen eleştirilerle birlikte değerlendirildiğinde başlıca şu çıkarımları yapmak mümkündür: Gerçek savaşın mutlak savaştan farklılık arz ettiği, devlet, ordu ve hükümet arasındaki ayrımın yeni savaşlarda flu hale geldiği, hatta sivil-asker ayrımının zorlaştığı yeni bir döneme girilmiştir. Medya, özel askeri şirketler, hükümet-dışı kuruluşların işin içine girmesiyle dengesi bozulan savaşın aynı zamanda artık siyasi bir çizgide ilerlediğini söylemek de zordur. Kendine ait mantığa sahip günümüz savaşları, Clausewitz'in mottosunu tersine çevirmeye de adaydır. Yine Clausewitz'in savaşa yönelik istekliliği ile akılcılığı ön plana çıkarması onun bir çelişkisi olarak görülmektedir.

\section{Kaynakça}

Addington, L. H. (1994). The Patterns of War Since the Eighteenth Century, USA: Indiana University Press.

Aquinas, S. T. (2002[1225-1274]). Aquinas: Political Writings, Ed. ve Çev. R.W. Dyson, UK: Cambridge University Press.

Čajić, J. (2016). The Relevance of Clausewitz's Theory of War to Contemporary Conflict Resolution. Connections QJ 15, No. 1, 72-78.

Creswell, M. H. (2011). Clausewitz: The Debate Continues. Hilstory: Reviews of New Books, 39, 104-108.

Foucault, M. (2018). Toplumu Savunmak Gerekir. 8. Bask1. Çev. Ş. Aktaş, İstanbul: Yapı Kredi Yayınları.

Gat, A. (1992). Clausewitz and the Marxists: Yet Another Look. Journal of Contemporary History, Vol. 27, No. 2, 363-382.
Gray, C. H. (2000). Postmodern Savaş: Yeni Çatışma Politikaları. Çev. Derya Kömürcü. İstanbul: Alfa Basım Yayım.

Grotius, H. (2011[1625]). Savaş ve Barış Hukuku, Çev. S. L. Meray, İstanbul: Say Yayınları.

Gürcan, M. (2014). Savaşın Evrimi ve Teorik Yaklaşımlar. (Erişim:12.06.2018),http://www.bilgesam.org/Image s/Dokumanlar/0-163-2014040751bs2011-2-127178.pdf, 70-129.

Hahlweg, W. (2008[1980]). 19. Bask1 İçin Sonsöz: Clausewitz'in Düșüncelerinin 1972'den Beri Gelişimi ve Değiş̧imi. İçinde: Savaş Üzerine, Çev. Selma Koçak, (s.765-776). İstanbul: Doruk Yayınevi.

Haldun, İ. (2018[1377]). Mukaddime I, Haz. Arslan Tekin, İstanbul: İlgi Kültür Sanat Yayıncılık.

Herberg-Rothe, A. (2009). Carl von Clausewitz TodayThe Primacy of Politics in War and Conflict. World Security Network Newsletter, 1-7.

Hobbes, T. (2010[1651]) Leviathan veya Bir Din ve Dünya Devletinin Içeriği, Biçimi ve Kudreti, Çev. S. Lim, İstanbul: Yap1 Kredi Yayınları.

Irvine, D. D. (1940). The French Discovery of Clausewitz and Napoleon. The Journal of the American Military Institute, Vol. 4, No. 3, 143-161.

Kaldor, M. (2010). Inconclusive Wars: Is Clausewitz Still Relevant in these Global Times?. Global Policy, Volume 1, Issue 3, 271-281.

Kohn, G. C., (2006). Savaş Sözlüğü, Ankara: Doruk Yayınlar1.

Lebow, R. N. (1988). Clausewitz and Nuclear Crisis Stability. Political Science Quarterly, Vol. 103, No. 1, 81-110.

Lider, J. (1977). War and Politics: Clausewitz Today. Cooperation and Conflict, XII, 187-206.

Machiavelli, N. (2007[1469-1527]). Savaş Sanatı, Çev. B. Hasan, İstanbul: Doruk Yayınevi.

Milevski, L. (2019). The Idea of Genius in Clausewitz and Sun Tzu. Comparative Strategy, 38:2, 139-149.

Münkler, H. (2010). Yeni Savaşlar, Çev. Z. Aksu Yılmazer, İstanbul: İletişim Yayınları.

New, L. D. (1996). Clausewitz's Theory: On War and Its Application Today. Airpower Journal, 08970823, Cilt 10, Sayı 3, 78-86.

Nielsen, S. C. (2007). The Tragedy of War: Clausewitz on Morality and the Use of Force. Defence Studies, Vol. 7, No. 2, 208-238.

Oyan Altuntaş, E. (2008). Clausewitz'in Savaş Kuramı İçinden "Terörizme Karşı Savaş" Stratejisi. Mülkiye, Cilt: 32, Say1: 260, 207-224.

Pappila, O. (2008). The Nature of War Today. Kungl Krigsvetenskapsakademiens Handlingar Och Tidskrift, Dikussion \& Debatt, 4, 69-73. 
Schuurman, P.(2014). Clausewitz on Real War. Peace Review: A Journal of Social Justice, 26, 372-379.

Sharma, V. S. (2015). Social Theory of War: Clausewitz and War Reconsidered. Cambridge Review of International Affairs, Vol. 28, No. 3, 327-347.

Simpson, E. (2017). Clausewitz's Theory of War and Victory in Contemporary Conflict. Parameters 47(4), 7-18.

Smith, D. (1994). Just War, Clausewitz and Sarajevo. Journal of Peace Research, Vol. 31, No. 2, 136-142.

Stone, J. (2007). Clausewitz's Trinity and Contemporary Conflict. Civil Wars, 9:3, 282-296.

Strachan, H. (2007). Annual Defence Lecture: War and Strategy. Chatham House, 1-16.

Şahin, Y. (2008). Küresel Çevre Sorunlarına Sahip 'İmparatorluk'ta 'Çokluk'la Bir Çıkış Yolu Aramak: Eleştirel Bir Değerlendirme. İçinde: M. Kayıkçı \& R. Ö. Dönmez (Ed.), Yeni İmparatorluk Çăğ , (s.5566). İstanbul: Say Yayınları.

Thucydides (2016 [1954]). Melian Diyalogu. İçinde: P. R. Viotti \& M. V. Kauppi (Ed.), Uluslararası İlişkiler Teorisi, (s. 83-87). Ankara: Nobel Akademik Yayıncilık.

Timeturk, (2010). Wikileaks, Diplomasinin 11 Eylül'ü Olacak. (Erişim: 29.11.2010), http://www.timeturk.com/tr/2010/11/28/wikileaksdiplomasinin-11-eylul-u-olacak.html

Tzu, S. (2010[MÖ 6. yy]). Savaş Sanat,, İstanbul: Arya Yayıncilik. van Creveld, M. (1991). The Clausewitzian Universe and the Law of War. Journal of Contemporary History, Vol. 26, 403-429.

Varlık, A. B. (2013). Savașı Tanımlamak: Terminolojik Bir Yaklaşım. Avrasya Terim Dergisi, 1 (2): 114-129.

Vasquez, J. A. (2015). Savaş Bulmacası, çev. Haluk Özdemir, Ankara: Röle Akademik Yayıncılık.

Veysal, Ç. (2010). Savaşın Felsefesi. İstanbul: Etik Yayınlar1.

von Clausewitz, C. (2008[1972]). Savaş Üzerine, Çev. Selma Koçak, İstanbul: Doruk Yayınevi.

von Oetinger, B., Von Ghyczy, T. \& Bassford, C. (2010). Clausewitz ve Strateji, çev. Zülfü Dicleli, İstanbul: Optimist Yayınları.

Wallach, Jehuda L. (1978). On War by Carl von Clausewitz; Clausewitz and the State by Peter Paret. The Journal of Modern History, Vol. 50, No. 1, 125128.

Waltz, K. N. (2009). Insan, Devlet ve Savaş: Teorik Bir Analiz, Ankara: Asil Yayın Dağıtım.

Williams, H., Wright, M. \& Evans, T. (der.) (2007). Uluslararası Illişkiler ve Siyaset Teorisi Üzerine Bir Derleme, Ankara: Phoenix Yayınları.

Yalçınkaya, H. (2008). Savaş: Uluslararası İlişkilerde Güç Kullanımı, Ankara: İmge Yayınevi.

Yalçınkaya, H. \& Türkeş, K. T. (2008). Yirmi Birinci Yüzyılda Çatışma Alanlarında Görülen Yeni Unsurlar. Güvenlik Stratejileri Dergisi, Sayı 7, 5589. 